\title{
Potentials and Effectiveness of the Tort of Deceit in Addressing Paternity Fraud Issues
}

\author{
Chinomnso John Okebie ${ }^{1}$, Elina Konstantinidou ${ }^{2}$ \\ ${ }^{1}$ Centre for commercial law Studies, Queen Mary University of London. \\ ${ }^{2}$ Faculty of Business \& Law, Anglia Ruskin University.
}

\begin{abstract}
Men are becoming increasingly concerned about misattributed paternity. The increasing use of genetic technologies in clinical research increases the potential for misattributed paternity to be identified. This review seeks to answer the question of whether the Tort of Deceit is effective in addressing issues of paternity fraud. The article assesses how the tort of deceit concepts and principles can be used to resolve misrepresentation cases of paternity fraud and to inform the effectiveness of the tort of deceit in resolving such matters. The article concludes that the tort of deceit can be used to claim settlement as it provided a form of legal solution for the damages suffered as a consequence of paternity fraud. Some of the elements of the tort of deceit include false representation, fact, Knowing or reckless as to whether the statement is false, whether there was reliance upon the representation and existence of damage suffered by the plaintiff. The association between material obligation and the burdens generated by parenthood implies that it is ethically acceptable for a man to establish that he is the legal and biological father of a child before accepting this financial liability. Therefore, the tort of deceit concepts can be used to resolve cases of paternity misrepresentation.
\end{abstract}

Keywords: Paternity Fraud, Tort of deceit, Legal procedure, Misrepresentation, Families, Technology, DNA.

\section{INTRODUCTION}

In the age of genetic technologies in clinical research, the possibility of identification of misattributed paternity has increased. However, there exists a discrepancy in the practices and mode of the approach used to identify paternity fraud cases. And as such, realistic analysis of the disclosure of paternal discrepancy is relatively rare [1]. DNA Paternity testing has been used to provide evidence of paternity fraud, exposing a mother's deceit and concealment of the real identity of the child's father. The tort of deceit, as a form of legal injury, provides a platform for tackling cases of paternal fraud that may arise from claims of settlements in property, compensation, 
and child support. The ethical justifications under Tort and Contract law allow for reimbursement claims for financial costs of child upbringing, mediation, and settlement hearings and deceit, among other damages $\left[{ }^{2}\right]$.

Fraudulent misinterpretation occurs when an individual intentionally hides the truth about the influence of an object that another person depends $\left[{ }^{1}\right]$. An instance illustrating deceit was when Marc Thompson grain future's executive torched his house in desperation for insurance money worth more than 700,000 American Dollars $\left[^{3}\right]$. His misconduct that caused the death of his mother warranted a 190-year prison sentence. Similarly, cases of paternal fraud as a form of misinterpretation warrants the father to claim settlement for damages incurred. Here, the tort of deceit provides a legal framework for the presentation of the evidence of damages by a party and claims of compensation by the complainant $\left[^{1}\right]$. It also allows for ease of quantification of damages by the defendant for adequate reimbursement. This article will seek to assess the potential of using tort of deceit in addressing the cases of paternity fraud through the review of literature and assessment of previous applications of the tort of deceit principles in solving cases of misrepresentation.

\section{THE ISSUE OF PATERNITY FRAUD (MISREPRESENTATION)}

Is the tort of deceit effective in addressing issues of paternity fraud? Often, in cases of paternal discrepancy where a man is wrongfully acknowledged as the biological father of a child, there is a fundamental supposition that the mother of the child misidentified the biological father knowingly with an intent of covering up the real identity of the child $\left[{ }^{2}\right]$. The deception in the child identity by mothers has left caused men to pay child support and bring up children that are not biologically theirs. In the context of assisted conception, paternal fraud can be unintentionally discovered. An example is during treatment that involves identification of blood groups and tissue matches $\left[{ }^{4}\right]$. Doubts in paternity can arise from the realization of a physiological disorder in a child and suspicion of infidelity at points of relationship breakdowns. Therefore, there appears the need to claim compensation for the damages and unfairness caused to the plaintiff. When analyzing such cases, the tort of deceit can be used as a framework for evaluation of the need to claim settlement. However, its implications dictate that the misinterpretation must have an aspect of materiality and must have also been invoked. This means that the effectiveness of the tort of deceit greatly relies the fact that the recipient must have relied on the misinterpretation, allowing them to be in a position to call of an arrangement (or relationship in this case) $\left[{ }^{5}\right]$. However, the question of whether it is justified to seek a settlement in such a case remains subject to debate. 
Therefore, considering liability and the burden of proof for establishing the liability for settlement should be critical factors to consider while measuring the magnitude or value of the recoverable damages.

\section{THEORETICAL FRAMEWORK}

There is a growing public demand for legal orchestrated solutions and guidelines for handling family-related problems. Paternity fraud has raised significant public debate on the different alternatives that are available for couples and families. ${ }^{1}$ Alternative methods of arbitration between claimants and defendants who have paternity issues are highly limited due to lack of procedures as well as the emotional and mental consequences that are accompanied by the final verdict of the problem. ${ }^{2}$ As the number of misappropriated paternity cases grow, there is a growing need for legal procedures that can help to create equity and justice in such situations while at the same time standing for the special interests of the children who are caught up between such cases. Families and couples continue to become more litigious when it comes to resolving children's custody and paternity disputes with farreaching financial, emotional, and social implications. ${ }^{3}$

Family roles and parental responsibility are significant issues that cannot be left out to be handled by alternative dispute resolution methods such as negotiation and arbitration. In such cases, the existence of family law has previously provided direction on how such matters are handled. Still, there is a high limitation in policy and procedures, which has been detrimental in the establishment of an informed and representative legal framework that can ensure equity and justice for all the parties. Paternity fraud involves deception, and it is not classified as a criminal offence which has limited the legal procedure outcomes in fully meeting the expectations of the parties involved fully. The family justice system is faced with a rapidly changing social set up, and family composition with paternity fraud cases becoming a significant problem mainly due to the high level of infidelity and unofficial

\footnotetext{
${ }^{1}$ Ibid 13 .

2 Padgett, Maegan. "The Plight of Putative Father: Public Policy v. Paternity Fraud." W. Va. L. Rev. 107 (2004): 867. 
marriages and family set up. Geographic mobility and high expectation of parents towards their children has increased the emphasis of the financial responsibility of parents and in this case especially fathers who in accordance to the family law are required to meet the financial needs of upbringing their children. ${ }^{4}$ The tort of deceit application in resolving paternity fraud is becoming an essential avenue for integrating legal procedures by handling the actions of a mother as deceit. ${ }^{5}$

In the English law, a recent case $P v B$ played an instrumental role in ascertaining the importance of considering tort of deceit application in domestic arrangements. Despite the acceptance of the use of the tort of deceit in a paternity fraud case and the success of ensuring a father is compensated for a mother's misrepresentation, there are a significant gap and conflict with the family law. ${ }^{6}$ For instance, the Matrimonial Causes Act of 1973 requires that husbands, even those who are not natural fathers, are required to pay maintenance for children born during the marriage, according to Section $25(4){ }^{7}$ This shows that despite the acceptance of the application of the tort of deceit in paternity fraud legal cases, there are laws that can be used to argue against its appropriateness. The tort of deceit can be used to promote equity and justice in the affairs of misappropriated paternity by ensuring that the negatively affected party is duly compensated. ${ }^{8}$ The tort of deceit procedures creates a legal environment where justice and equity can be attained in the cases of paternity fraud. The res judicata principles are instrumental hindrances towards the application of paternity fraud in the legal system procedures, which is a new family law practice. The availability of DNA testing has been instrumental in facilitating

\footnotetext{
${ }^{4}$ Ibid 73

${ }^{5}$ Ibid 13

${ }^{6}$ Murray, Paula C., and Brenda J. Winslett. "The Constitutional Right to Privacy and Emerging Tort Liability for Deceit in Interpersonal Relationships." U. Ill. L. Rev. (1986): 779.

${ }^{7}$ Ashton, Jeanette. "Financial provision following divorce: Revisiting the matrimonial causes act 1973 in light of Wyatt v Vince." Student Law Review 76 (2015): 30-31.

${ }^{8}$ Wiegers, Wanda. "Fatherhood and Misattributed Genetic Paternity in Family Law." Queen's LJ 36 (2010): 623.
} 
the disestablishment of paternity. ${ }^{9}$ Besides, the need to balance the best interests of the child in question and establish justice for the non-biological father shows the importance of creating a universally accepted legal framework for addressing paternity fraud. ${ }^{10}$

\section{THE TORT OF DECEIT RULE (LEGAL PROCEDURES AND PROCESSES)}

The tort of deceit is where a fraudulent misrepresentation by the accused party is explicitly directed to the plaintiff, demonstrating that the individual suffers a loss as a result $\left[{ }^{1}\right]$. Paternity fraud is a dilemma that was not anticipated by the legal system, as it finds itself in a position of the susceptibility of being unequipped to handle such cases $\left[{ }^{6}\right]$. Some of the most multifaceted circumstances in parenthood are those where the paternity of a child is non-consensual, deceitful, or misattributed. For instances involving misattributed paternity, it is safe to assume that both the child and the non-biological father are unaware that they do not have any biological connection until a paternity test is done $\left.{ }^{7}\right]$. Furthermore, the paternal discrepancy is a modern reality with severe practical implications and legal consequences for all parties involved. The tort of deceit, therefore, can be used as a legal framework to identify the types of misinterpretation involved in any particular case of paternity $\operatorname{fraud}\left[{ }^{8}\right]$.

To ascertain whether a fraudulent claim will succeed, some courts simply seek to determine whether all the elements of the tort have been proven[ $\left.{ }^{1}\right]$. This is aimed at establishing the liability without accounting for the appropriate application of the tort of deceit. It is important to consider available to the plaintiff, once the remedies for misinterpretation have been established $\left[{ }^{9}\right]$. This may include termination of the contract by the offended party, insurance and protection by the court to offer compensation, or claiming settlement for the damages caused by the fraudulent misinterpretation.

The tort of deceit can be mainly used to claim settlement as it provided a form of legal solution for the damages suffered as a consequence of paternity fraud. In common law, both torts of deceit and negligent misinterpretation have been pleaded in the context of misattributed paternity. The effectiveness of the approach stipulated by the

\footnotetext{
${ }^{9}$ Norton, Sarah, and Shelby Maroselli. "Redefining Fatherhood: Approaching the Presumption of Legitimacy and Other Methods of Paternal Determination in the Age of DNA Testing." (2015).

${ }^{10}$ Ayres, Susan. "Paternity Un (certainty): How the Law Surrounding Paternity Challenges Negatively Impacts Family Relationships and Women's Sexuality." J. Gender Race \& Just. 20, (2017): 237.
} 
Tort Law relies on whether there is substantial proof of false representation provided by the offender, intention and action of the accuser depending on the provided information and proof of damage suffered by the offended as a result of this fraudulent misinterpretation $\left[{ }^{10}\right]$. On the upside, the defence against false deceit in cases of paternity fraud is crippled by the fact that Contributory negligence (the act of disregard in purposefully misleading someone) cannot be invoked to the offence of "its" magnitude $\left[{ }^{11}\right]$.

\section{ANALYSIS}

\section{Context of Paternity Fraud}

In recent times, the United States, Australia, and England there has been an increase in the calls to expand the use of the tort of deceit in resolving the complex cases of misattributed paternity. Previously, the tort of deceit was mainly applied in commercial transaction cases. Whereas in some cases such as in England the tort of deceit was successfully used in $P v B$ and $A v B$ cases in other contexts such as the Australian context it was rejected by the court in Magil v Magil case $\left[{ }^{16}\right]$. Over the years, there has been a gap in the creation of a common approach for handling the ballooning paternity fraud cases. Paternity tests through new technology have provided a breakthrough in the collection of misattributed paternity evidence to prove the deceit of the mother who intentionally lies to a man that he is the biological father of her children $\left.{ }^{6}\right]$. The tort of deceit is an informal avenue for addressing paternity fraud cases that occur due to the deceit resulting from the mother of the children who convinces a man to take responsibility for the children that are not biologically sired by him. In the contract law, people are awarded damages based on the breach of the existing contract between two parties[5]. In contrast, the cases of deceit in tort law, a misrepresenter will be liable to all the direct consequences of their fraudulent behaviour, even in the instance where the losses involved are not foreseeable $\left[{ }^{7}\right]$.

\section{Addressing Parental Responsibility}

Technological advancements in clinical and medical research have provided a breakthrough concerning paternal testing and evidence of discrepancy $\left[{ }^{4}\right]$. Misattributed paternity (where the purported father is not the biological parent) is an incidental finding that is secondary to genetic testing conducted for families or in the genetic research setting $\left[{ }^{2}\right]$. As argued by the New Zealand Commission of 2005 , genetics play a major role in the legislative laws of parenthood. However, the report did not provide an overall view of individualism and the 
relationship between genetics and parenthood $\left[{ }^{13}\right]$. Refutable evidence of genetics show biological similarities between a child and the parents automatically denotes parenthood $\left[{ }^{2}\right]$. The evidence of paternity fraud and deceit from the mother of children who deliberately sways a man into accepting legal responsibility of the children, calls for the use of the tort of deceit approach in addressing the cases of misattributed paternity are on the rise $\left[{ }^{4}\right]$.

The association between material obligation and the burdens generated by parenthood implies that it is ethically acceptable for a man to establish that he is the legal and biological father of a child before accepting financial liability $\left[{ }^{1}\right]$. Hence, issues of accepting accountability in the event of paternal discrepancy are rooted in financial or child support. However, some men accept full parental liability of their children irrespective of a biological relationship. One major case that can best illustrate parental responsibility as one of the significant elements affecting the tort of deceit is the Magill v. Magill paternity fraud case $\left[{ }^{10}\right]$.

Critiques illustrate that the Court of Appeal did not need to analyze the paternal misinterpretation pertaining to the tort of deceit and its implications $\left[{ }^{12}\right]$. Questions arose of whether or not the law under the tort of deceit should have been applied differently within this context. The responsibility of fatherhood should not be used instrumentally in supporting charges of paternal discrepancy concerning the tort of deceit $\left[{ }^{6}\right]$. Moreover, it cannot be used as a determinant of paternal fraud in instances where settlement is demanded under similar circumstances.

Similarly, parenthood is meant to bring parental responsibility with different obligations and rights. Analysis of a similar paternity fraud case of Hodge v. Craig in 2012 strongly illustrates that parental responsibility cannot be used as a determinant of paternal fraud $\left[{ }^{5}\right]$. In this instance, there was an appeal to establish the legitimacy of the Court under the laws of Tennessee to allow a former spouse of a mother to sue and file for charges against his former wife for paternity fraud $\left[{ }^{5}\right]$.

Arguably, this case offers more insight into the extrinsic factors that affect cases of paternal fraud where divorce is involved; and as such, the legal framework of the judicial system can be viewed as instrumental in thinning out cases of fraud with implications to the tort of deceit and negligence $\left[{ }^{7}\right]$. Also, it is clear that paternity laws are based on the liability theory for genetic or biological contributions that demands that fathers be held accountable for procreation and reproducing children regardless of their legal presence in the child's life. 


\section{Paternal Fraud}

It is important to note that in many settings, paternal fraud is viewed as a civil crime as most cases warrant the use of the tort of deceit approach in sentencing. Similarly, in the world of genomics, DNA paternal tests have been used to resolve most of these cases of paternal discrepancy as demanded by the Child Support Agency[ $\left.{ }^{7}\right]$. DNA testing can, therefore, be deemed necessary in areas of specialities other than medicine and criminal law. Cases of paternal fraud stem from a variety of causes.

In as much as many fathers strive to be significant features in their children's lives, problems can arise as a result of the claims of discrepancy relating to the tort of deceit. This makes it easier to deduce that activists of laws involving paternity fraud may have no functional relationships with children throughout the numerous court hearings $\left[{ }^{6}\right]$. This is a notion that other authors and researchers strongly dispute. Therefore, it is for this reason that many judicial systems refute non-biological fathers (who found out their status from DNA testing) to lay claims of paternity fraud against their spouses (mothers of the children) in relation to the laws of tort, because of their effects to the children.

Upon the analysis of the paternal fraud case of Steve v. Wendy of 1998, which had similar implications to that of Hodge v. Craig, it is clear that some cases have detrimental impacts to the children in question $\left[{ }^{15}\right]\left[{ }^{5}\right]$. The court dismissed the case on the grounds of the public policy due to the complaint's (Steve) intention to cause distress and failure to recognize that the child was the most significant party in such fraud cases $\left[{ }^{15}\right]$. Some of the points that can be argued from this case include the fact that children would undergo mental suffering as a result of the proceedings if the court failed to intercede.

\section{Tort of Deceit}

Having carefully evaluated the case files, deductions can be drawn concerning the approach of the tort of deceit in resolving cases of paternal fraud. For instance, representations concerning the relationship between the plaintiff and defendant, including claims of paternal discrepancy should not be viewed as the root causes of the consequences that arise from the various cases $\left.{ }^{8}\right]$. In Australia, the case of Magill v. Magill was dismissed by the court since it did not warrant the application of the tort of deceit in mediation and settlement $\left[{ }^{10}\right]$.

However, it is not clear whether the reason for dismissal was because the couple in question were engaged, and whether the case could have taken a different turn if they were married[11 ${ }^{11}$. Concerning the elements of the tort 
of deceit, there has to be considerable evidence of false representation provided by the offender, intention and action of the accuser depending on the provided information $\left[{ }^{9}\right]$. Subsequently, the plaintiff has to offer evidence of the damages suffered as a result of reliance upon this misinterpretation.

According to related literature by Draper in 2007, DNA paternal testing comes across as an influential factor in determining and exposing the cases of infidelity $\left[{ }^{4}\right]$. This realization is considered prominent enough to arouse feelings and emotions of betrayal, grief, disgust, and self-dejection, leading to them seeking to get settlement under the tort of deceit $\left[{ }^{2}\right]$. The case of Magill v. Magill gives a considerable illustration of the point mentioned above since the man's sole claim was that the wife acquired financial support from him, even with the knowledge that the child was not his. This drove him to press charges against his wife on the grounds of paternal fraud with the intent of getting a settlement for the damages he had suffered. Draper (2007) makes analysis of similar cases in the United Kingdom involving the use of the tort of deceit in resolving paternity fraud cases $\left[{ }^{4}\right]$.

The findings of the study conducted by Boyd in 2007 show that in addressing cases of paternal fraud, the court takes into consideration the different accounts such as settlement in the form of compensation for the damages resulting from the deceit, the order of contempt, and the charges laid against an individual, to determine the severity of the violations $\left[^{2}\right]$. He takes a stand from a feminist point of view, arguing that role of bio-genetics could be disregarded during the registration of birth (done by the mother) and intentionally approved of the need for formal legal equality in paternal fraud cases involving tort of deceit $\left[{ }^{2}\right]$. This implied that in the occasion that it was to be acknowledged, the father would be stripped of the privilege to subordinate the mother's choice of the child's surname. Nevertheless, claims of paternal fraud would only arise when both the figures of parenthood neglected their responsibilities. Boyd (2007) argues that neither of the party's rights could be infringed regardless of the case as the courts of law stipulate $\left[{ }^{2}\right]$. This is a significant challenge for the judges to make a final judgement or ruling the decision for compensation.

\section{Challenges of applying Tort of Deceit in Misattributed Paternity Cases}

Despite the trials of the application of the tort of deceit in the United States, England, Australia and Ireland cases of misattributed paternity, there is a consensus that its application is problematic especially in terms of proving representation which was the case in Magil case law. In the Australian court, the need to prove representation proved difficult due to the view that it was contrary to the existing public policy in that it unnecessarily interfered with the party's private life. This shows that the need to prove false misrepresentation of paternity is one of the 
largest problems in the application of the tort of deceit in such cases. Where there is sufficient evidence to show that there is misrepresentation tort of deceit can be effectively implemented. Besides the issue of proving misrepresentation, there is a significant issue in terms of how the damages will be counted and compensated. The challenge of proving damages and also counting them for compensation makes it difficult to use the tort of deceit in resolving the paternity fraud cases. Monetizing human relationship is seen as morally offensive which denotes that recovering the costs incurred in rearing a child is not conceivable $\left[{ }^{16}\right]$.

\section{CONCLUSION}

Paternal fraud cases have been fast on the rise due to notable technological advancements. Paternal DNA testing that has developed under genomics has provided a breakthrough in the assertion of the paternal discrepancy. It can be used to show infidelity in a relationship. This leads to the need for compensation for time, money, and emotions that men could have invested in bringing up children that are not biologically theirs, however, this occurs only in the cases where the plaintiff seeks settlement for the damages incurred. As such, the tort of deceit can be used as a legal framework for determining the severity of damages and to calculate recoverable compensation to be offered to the plaintiff. Different elements of the tort of deceit, including the materiality influence the decisions of the courts of law. Some cases reviewed show the lack of substantial evidence of damage or fallen short of other aspects of misinterpretation, making them null. The legal system needs to investigate the reported cases of paternal fraud further, to ensure transparency and meaningful settlement, be there any. The tort of deceit can be used as a tool to approve or dismiss cases on the merit of their legitimacy. It is also crucial to consider the role of the children in instances of the paternal discrepancy. 


\section{References}

[1]. Baker, K. K. (2004). Bargaining or Biology-The History and Future of Paternity Law and Parental Status. Cornell JL \& Pub. Policy, 14, 1.

[2]. Boyd, S. B. Gendering Legal Parenthood: Bio-Genetic Ties, Intentionality, and Responsibility" (2007). Windsor YB Access Just., 25, 63.

[3]. Derry v. Peek, 14 App. 337 (1889).

[4]. Draper, Heather. "Paternity fraud and compensation for misattributed paternity." Journal of medical ethics 33, no. 8 (2007): 475-480.

[5]. Hodge v. Craig, 382 S.W.3d 325 (Tenn. 2012).

[6]. Jacobs, M. B. (2004). When Daddy Doesn't Want to Be Daddy Anymore: An Argument Against Paternity Fraud Claims? Yale JL \&. Feminism, 16, 193.

[7]. Kwok, Emily, and Dianna T. Kenny. "Misattributed paternity disputes: The application of the collaborative practice as an alternative to court." AUSTRALASIAN DISPUTE RESOLUTION JOURNAL 26, no. 3 (2015): 127-136.)

[8]. Lawton, Zoë. "Non-Consensual, Deceitful and Misattributed Paternity." (2013).

[9]. Lowe, Georgia, Jonathan Pugh, Guy Kahane, Louise Corben, Sharon Lewis, Martin Delatycki, and Julian Savulescu. "How should we deal with misattributed paternity? A survey of lay public attitudes." AJOB empirical bioethics 8, no. 4 (2017): 234-242.

[10]. Magill v. Magill, 816 S.W.2d 530 (Tex. App. 1991).

[11]. Monaghan, Nicola, and Chris Monaghan. Beginning Contract Law. Routledge, 2013.

[12]. Muhammad, Saliu Adam, Xiangtao Chen, and Liao Bo. "Predictor Variables' Influence on Classification Outcome in Insurance Fraud Detection." International Journal of Hybrid Information Technology 8, no. 5 (2015): 41-50.

[13]. New Zealand Law Commission. (2005). New issues in legal parenthood (report 88). Wellington, New Zealand, URL (consulted September 2007): http://www. Law-com. govt.z/UploadFiles/Publications/Publication_91_315_R88.Pdf.) 
[14]. Okebie, Chinomnso, "When the Genes Do not Fit: Towards A Legal Framework for Addressing Paternity Fraud" (December 16, 2019). Available at SSRN: https://ssrn.com/abstract=3659875 or http://dx.doi.org/10.2139/ssrn.3659875. accessed 27 march 2020.

[15]. Rauschenberger, Henry S. "To Kill a Cuckoo Bird: Louisiana's Dual Paternity Problem." La. L. Rev. 77 (2016): 1177.

[16]. Steve v. Wendy, 960 P.2d 510, 77 Cal. Rptr. 2d 706, (1998).

[17]. Connolly U. Paternity fraud and the tort of deceit. Q. Rev. Tort L. 2008;3: 24. 